\title{
Reasons behind divorce in Palestine from the legal judge's and Mufti's perspectives and suggested remedies
}

\author{
Mohsen Sameeh Saeed Khalidi ${ }^{\bullet}$ Ahmed Awad Amin Raba' ${ }^{\star}$
}

${ }^{1}$ Department of Osoul Aldeen, Faculty of Shariah, An-Najah National University, Palestine.

${ }^{2}$ Department of Methods of Teaching, Faculty of Education and Teacher Training, An-Najah National University, Palestine.

${ }^{*}$ Corresponding author. E-mail: ahmedawad_amin@yahoo.com

Accepted $14^{\text {th }}$ March, 2019.

\begin{abstract}
This study aimed at investigating the reasons behind divorce in the Palestinian society. The study analyzes legal judge's perspective and Mufti's perspective for this phenomena. To accomplish this study, the researchers used two questionnaires: a 25-item questionnaire about the reasons behind divorce and another questionnaire of 20 items about the suggested remedies for the causes. The two questionnaires were distributed among (13) male Muftis at Dar Al-Ifta' Al-Falasteeniyya who served as the respondents and provided the data for this research in the year 2018. The findings of this study, showed that the main reasons behind divorce are social, emotional, unawareness in choosing the right partner and misusing of technology applications regardless of the respondents age and qualification. Findings also showed that the majority of divorce rate occurs in the period of engagement. Based on these results, the researchers recommended that the awareness of the couples of the negative impact of the interference of parents with what happened between them is basic in stopping divorce. Another recommendation is the need for specialists to avoid and solve marital problems and focus on religious and moral aspects when dealing with spouses in addition to appropriate use of technology implementations.
\end{abstract}

Keywords: Reasons, divorce, Palestine, judge's perspectives, Mufti's perspectives, remedies.

\section{INTRODUCTION AND THEORETICAL BACKGROUND}

Marriage contract is the first step in building a family and the couples are considered as the main cell for building it. Family cohesion has great social activity in all its physical spiritual, ideological and economic aspects. Marriage is not just a sexual relationship but it is a holy and strong association between man and woman, society justifies their existence through having children and upbringing them social, moral and religious (Settersten, 2015). Sometimes marriage faces misunderstanding and disconformities and this negatively affects the satisfaction of the innate needs of humans that leads to marital differences, if untreated well the happiness and comfort will be lost. Then they lost love and respect which are the most important features of marriage couples (Sinha, 2013). Any imbalance in the marriage system negatively reflects on the life of family and marital life. Many of changes that happen in marital life, different personality patterns and behavioral styles of the couple may be the decisive factors for survival or dissolution of the marriage and may be the nature of cooperation or conflict. From this point, the marriage becomes difficult relation that leads to emotional divorce (Employment and Social Development Canada, 2014a).

In light of the global changes in terms of technological revolutions and the exit of women to work among others raised the status of women and made them equal to men has affected the men-women relationship negatively. As a result, the rate of divorce in western countries, for 
example in the United States increased by $40 \%$ in the third millennium and moved to the Arab countries for example in Saudi Arabia by $50 \%$, Qatar by $23 \%$ and Bahrain 35\% (Al-Gharaibeh and Bromfield, 2012).

In view of the Palestinian society, this percentage is increasing according to official statistics which indicates that the divorce rate has approached $20 \%$ according to the Palestinian Central Bureau of Statistics in 2013, the total number of divorces recorded in the Islamic courts in the West Bank (4095 cases in 2013), (3749 cases in 2012). This shows the extent of the annual increase (Palestinian Central Bureau of Statistics, 2018). Based on these grounds, this study aims to investigate the reasons of the divorce in Palestinian society, analysis of Judges and Muftis' perspectives and suggest the remedies. The importance of this study stemmed from its focus on an essential social issue that threatens the textile community to demolish leaving long-term effects in the long run. This study can have remedies to reduce the divorce rate and its impact on society and the family.

\section{Statement of problems}

Family has a great importance in Islam and it is the first responsible for upbringing the generation in psychological and physical form. It should be built in a great deal of harmony. According to data published by the competent authorities Palestinian Central Bureau of Statistics (PCBS) divorce in Palestine society is increasing significantly. This increase is comprehensive in all areas of Palestine and this study seeks to analyze the reasons that lead to divorce and come up with the best interpretations and reach to the deepest and the best remedies.

\section{Questions of the study:}

1. What are the views of Muftis at Dar Al-Ifta' AlFalasteeniyya on some the reasons of divorce?

2. What are the views of Muftis at Dar Al-Ifta' AlFalasteeniyya on some suggestions for the divorce problem?

\section{LITERATURE REVIEW}

Since divorce is an international destructive phenomenon, the researchers revised literature review locally, regionally and globally. Similarities among cases were highlighted and so were the suggested remedies.

Shalaby (1992) deals with the issue of divorce and its importance to rely on intensive analysis of the official records in this regard, which are located in the Shari'a Court of Ramallah and the Sharia Court in Bir Zeit City for the years 1986-1989. The study included a number of statistical tables and indicates the documentation and diligent work in reviewing the records; and is expected to be a useful entry for many researchers in this field in the future. Statistical tables constitute the basis for establishing a systematic basis for the analysis of files of Islamic courts statistically (Divorce in the Ramallah, it is a social statistical study).

Al-Maliki' (2001) focused on identifying the most important reasons for divorce and its effect on divorcees, he put hypotheses for direct and indirect reasons. The study found that most divorcees are young and of tender age, the less educated women are more divorced. The researcher found the importance of the nature of housing and its impact on the phenomenon of divorce and the researcher found in his study that the majority of the divorce occurred at the request of divorcees. The researcher recommended rehabilitation of divorced women physically and morally through special institutions to deal with the effects of the phenomenon of divorce (The phenomenon of divorce in the United Arab Emirates and the causes, trends, risks and solutions).

Ayyash (2004) aimed at finding out the reasons for divorce and how to deal with it to find solutions to it from the point of view of Islam. The method used in this study was to study the case by interviewing a sample of divorced women in Al-Bireh, 30 out of 63 divorce cases representing the study community. The researcher came up with a set of results that explained the reasons for the divorce between couples and the most important reasons: travel of a man, the difference of spouses, abusive husband in the use of the right granted, interference of parents in marital life and infertility. He recommended that the researcher work to eradicate these causes and that through the awareness of the couple to the dangers to work to avoid them so that the family remains stable, then the spouses, children, relatives and the community feel calm and tenderness (Al-Azozuni, 2016; As-Sartawi, 2012; Scruton, 2012).

The study aimed at describing and analyzing the phenomenon of high rate of divorce from social, cultural and economic perspectives. The tools used were interviewing a number of male and female divorcees and observation in the field. The result of the analysis was that a set of social, cultural, and economic standards, on which the society based its relationships and connections is the main reason behind the deterioration of the emotional relationship between the spouses and all related factors. The researcher presented a number of recommendation, the most important was to boost the awareness of society on partner selection guidelines, respect of the privacy of the couple and post-marriage self-reliance (Social and cultural variables of divorce phenomenon).

Al-Khatib (2009) sought to reveal the impact of the social changes that swept through the Saudi society and led to the high rate of divorce in Saudi society. She also sought to know the most important factors leading to divorce from the perspective of a group of divorced Saudi women, the study aimed to focus on the most important 
social factors that led to high divorce rates in Saudi society. The most important tools used are interview of a group of divorced women and the use of an open-ended questionnaire.

The results of the study indicate that the reasons for divorce from the point of view of Saudi women is the lack of responsibility, emotional drought, marital infidelity, the difference of the couples' personalities and sexual problems (social changes and their impact on the high rates of divorce in the Kingdom of Saudi Arabia from the perspective of Saudi women) (Hawkins et al., 2012).

Tuffaha (2010) aimed to look at the phenomenon of divorce from Shariah perspective that can alleviate the increasing divorce rates. This study was carried out through the inductive method. The study by analyzing the causes of divorce, reached many results. The most important of which was the violation of Shariah rules in the marriage or divorce process, thereby augmenting the reasons for divorce and failure to observe the Shariah principles in the adjustment of disputes between spouses before divorce, although divorce is viewed as a phenomenon that is destructive to the family, which would adversely impact the stability of the society (legal measures to limit the occurrence of divorce in Jordanian society) (Hawkins et al., 2012).

Masoud (2013) in Egypt identifies the social, psychological and economic damage resulting from divorce for girls in the early stage of marriage; he used more than a tool for example: questionnaire and interview. After the study, the following results are shown and the most important ones are: The problems dealt with within the treatment model in the sense of economic problem such as financial burdens, social problem such as her poor relation with her family and psychological problem such as the psychological stress resulting from the society's view (Bakalar, 2010; Temke, 2006; Allen et al., 2005).

The most important recommendations were to educate the family about how to deal with divorced women and help her solve her psychological problems and train her to open a project to finance economically and community awareness that divorce is her fault and it has many reasons. (Practice the treatment model in the sense of serving the individual to mitigate the damage caused by divorce in the early stage of marriage)

Stein (2012) In The United State of America "Cambridge" tried to link the role of work and divorce and also tried to link economic crises and divorce rates. The method used in this study was study case, and the result was closed link between divorced rate and the economic situation and all the divorced female were from the women who married early (Business cycles and divorce: Evidence from microdata).

Heller and Recoules (2013) in France emerge the common relationship between the divorce rates, divorce rules and the social acceptance, this study reached to that the economic changes in the life need to permanent review to the divorce rules (Changes in divorce patterns: Culture and the Law) .
Vitanen (2014) in United States of America explained the relationship between the laws of marriage and trust in society. This means that divorce laws are easy and this is reflected in the social cohesion on the one hand and on the community on the other. Confidence at the individual level (self-confidence) and trust at the social level (trust in society) its values and standards are very important, then the results were consistent with other studies in the United States. The divorce revolution and generalization trust: Evidence from United States 1973-2010.

\section{Critical view of previous studies}

After a deep reading of the previous studies, which are important for the researchers, these studies took several trends with regard to divorce, which focused on the economic, legal and social, and also on the psychological side of the divorcees. The results of the previous studies have a significant impact on the understanding and perception of the researchers who hope through this study to add a new contribution to those results. The previous studies analyzed divorce and reached to suggested remedies and recommendations. Foreign studies have reached results that are not consistent with the results of Arab studies due to the social, economic and cultural differences between them.

\section{METHODOLOGY}

This section specifies the steps and the methodology taken in carrying out the research endeavor. In it, the researchers presented the population and the sample of the study, as well as the practical procedures used to build and describe the study tools. It also illustrated the types of statistical tests used in this study. Furthermore, it included a description of the reliability and validity of the study instrument.

\section{Instrumentation}

For the purpose of data collection, the researcher has designed two different questionnaires so that he could survey the views of Muftis at Dar Al-Ifta' Al-Falasteeniyya on the reasons of divorce, and on some suggestions for such a problem. The first questionnaire consists of 20 items, whereas the second one consists of 21 items. The two questionnaires were distributed among 13 male Muftis as there are no female muftis

\section{Population}

The population of the study consists of all Muftis at Dar Al-Ifta' Al-Falasteeniyya in west bank in Palestine with a total number of 13 male Muftis. 


\section{Sample of the study}

The sample of the study consists of all muftis in the West Bank of Palestine (13) male Muftis at Dar Al-Ifta' AlFalasteeniyya in 13 different Palestinian cities, all of them are between 45-60 years old served as the respondents and provided the data for this research in the year 2018. Five of them hold MA degree in Islamic studies while the rest of the Muftis hold BA in the Islamic Studies. All of them have the same profession call "Mufti".

\section{Instrument validity}

The instrument of the study was reviewed by some Muftis who recommended its validity after certain modification, and the researcher got the questionnaire in its final form.

\section{Instrument reliability}

As for the reliability of the study instrument, Cronbach's Alpha equation was used to extract the reliability of the instrument. reaching $71.1 \%$. This value indicates that the tool has an appropriate stability and satisfies the purposes of this study.

\section{Statistical analysis}

After collecting the data, it was sent to be processed by the well-known computer program "The Statistical Package for Social Science" (SPSS), then the percentages, the balanced means in addition to One Sampled-Test were used.

\section{RESULTS}

Positive items were given (4) points for each (Strongly agree) answer, (3) points for each (Agree) answer, (2) points for each (Disagree) answer and (1) point for each (Strongly disagree) answer. For results interpretation, the scale shown in Table 1 was used for the response's percentages.

\section{Results related to the first question "What are the views of Muftis at Dar Al-Ifta' Al-Falasteeniyya on the reasons of divorce?"}

To answer this question, the researcher used the average score distributed by statement, dimension. Results are shown in Table 2.

Table 2 shows that the views of Muftis at Dar Al-Ifta' AlFalasteeniyya on the reasons of divorce was very high on items $2,3,10,11,12,13,16,19$, where its percentage was more than $80 \%$, high on items $1,5,7,9,14,17,18$, where its percentage was between 70 and $79 \%$, medium on items $(4,6,8,15)$ where its percentage was between 60 and $69 \%$, low on item (20) where its percentage was between 50 and $59 \%$. Responses' total score was high, as its percentage was $75.75 \%$.

The study results indicate that the highest reasons for divorce from the perspective of the study participants were related to the general weakness of society with the risks of divorce and its negative effects, technological development and the spread of social media such as Facebook and others. The lack of patience of both spouses and resort to divorce when any problems occur, age disparity between spouses, leads to weakness in understanding in their married life, the interference of parents with what happens negatively between spouses.

\section{Results related to the second question "What are the views of Muftis at Dar Al-Ifta' Al-Falasteeniyya on some suggestions for the divorce problem?"}

To answer this question, the researchers used the average score distributed by statement, dimension. Results are shown in Table 3.

Table 4 shows that the views of Muftis at Dar Al-Ifta' AlFalasteeniyya on some suggestions for the divorce problem was very high on items $(1,4,6,7,8,9,10,11$, $12,13,14,17,18,21)$ where its percentage was more than $80 \%$, high on items $(2,3,5,16,19,20)$ where its percentage was between 70 and $79 \%$. Responses' total score was high, as its percentage was 78.5.

The study results indicate that the highest preferred solution to the issue of divorce from the perception of the study sample were related to young men and girls should be warned against the seriousness of pre-marital relationships; non-interference by the parents, but as it is most likely that for the benefit of the couple, the selection of the other partner should be based on the appropriate standards and criteria. The patience of both spouses keep divorce to the last possible decision. Society awareness of the risks of divorce is in accordance with Abuzant (2016) and Alan et al. (2012).

\section{Results of the first hypothesis}

There are no significance statistical differences at the significance level $(\alpha=0.05)$ in the views of Muftis at Dar Al-Ifta' Al-Falasteeniyya on the reasons of divorce".

A one-sample t-test was computed to compare the views of Muftis at Dar Al-Ifta' Al-Falasteeniyya on the reasons of divorce (Table 5).

Table 5 shows that there are significance differences at the significance level $(\alpha=0.05)$ in "the views of Muftis at Dar Al-Ifta' Al-Falasteeniyya on the reasons of divorce" 
Table 1. Responses' percentage scale.

\begin{tabular}{ll}
\hline Responses' degree & Percentage \\
\hline Very low & Less than $50 \%$ \\
Low & From $50-59 \%$ \\
Medium & From $60-69 \%$ \\
High & From $70-79 \%$ \\
Very high & $80 \%$ or more \\
\hline
\end{tabular}

Table 2. Means and percent means for the items.

\begin{tabular}{|c|c|c|c|c|c|}
\hline No. & Order & Item & Means * & $\begin{array}{c}\text { Percent } \\
\text { means }\end{array}$ & $\begin{array}{l}\text { Responses } \\
\text { degree }\end{array}$ \\
\hline $20-$ & 20 & Early marriage & 2.35 & 58.75 & Low \\
\hline $15-$ & 15 & Girls production & 2.57 & 64.25 & Medium \\
\hline $6-$ & 6 & The disparity in the academic degrees between them & 2.71 & 67.75 & Medium \\
\hline $8-$ & 8 & Migration abroad to look for jobs & 2.71 & 67.75 & Medium \\
\hline 4- & 4 & The rise in the cost of marriage such as over-dowry and others & 2.78 & 69.5 & Medium \\
\hline $5-$ & 5 & Inequality between spouses in terms of lineage & 2.92 & 73 & High \\
\hline 7- & 7 & Lack of independent housing due to high prices of apartments & 3 & 75 & high \\
\hline $14-$ & 14 & $\begin{array}{l}\text { Both spouses' attempt especially the husband to take control of } \\
\text { the house }\end{array}$ & 3 & 75 & high \\
\hline $17-$ & 17 & $\begin{array}{l}\text { The speed of seeking girl's hand in marriage and the length of } \\
\text { the engagement period }\end{array}$ & 3 & 75 & High \\
\hline $12-$ & 12 & $\begin{array}{l}\text { The relationship between the couples before the legal } \\
\text { engagement-Contract- }\end{array}$ & 3.07 & 92.5 & Very high \\
\hline $16-$ & 16 & $\begin{array}{l}\text { The general weakness in guidance of spouses by those who } \\
\text { around them, when there is a problem }\end{array}$ & 3.07 & 92.5 & Very high \\
\hline $9-$ & 9 & $\begin{array}{l}\text { High unemployment and inability of the husband to meet } \\
\text { household needs }\end{array}$ & 3.14 & 78.5 & High \\
\hline $2-$ & 2 & $\begin{array}{l}\text { Satellite TV and the broadcast of serials and films such as } \\
\text { Turkish ones and others }\end{array}$ & 3.28 & 82 & Very high \\
\hline $10-$ & 10 & $\begin{array}{l}\text { Unawareness of the couples and the shortened marital } \\
\text { relationship to sex }\end{array}$ & 3.28 & 82 & Very high \\
\hline $13-$ & 13 & $\begin{array}{l}\text { Lack of awareness in the basis of choosing the right partner, } \\
\text { such as looking for her job or her beauty or other things. }\end{array}$ & 3.28 & 82 & Very high \\
\hline $19-$ & 19 & $\begin{array}{l}\text { The general weakness of society with the risks of divorce and its } \\
\text { negative effects }\end{array}$ & 3.35 & 83.75 & Very high \\
\hline $1-$ & 1 & $\begin{array}{l}\text { Technological development and the spread of social media such } \\
\text { as Facebook and others }\end{array}$ & 3.5 & 78.5 & High \\
\hline $18-$ & 18 & $\begin{array}{l}\text { The lack of patience of both spouses and resort to divorce when } \\
\text { any problems occur }\end{array}$ & 3.5 & 78.5 & High \\
\hline 3- & 3 & $\begin{array}{l}\text { Age disparity between spouses, leads to weakness in } \\
\text { understanding in their married life }\end{array}$ & 3.57 & 89.25 & Very high \\
\hline \multirow[t]{2}{*}{$11-$} & 11 & $\begin{array}{l}\text { The interference of parents with what happens negatively } \\
\text { between spouses }\end{array}$ & 3.57 & 89.25 & Very high \\
\hline & & Total & 3.03 & 75.75 & High \\
\hline
\end{tabular}

*The highest degree to the item is (4) points.

on total score and at all items where the significance level for ( $t$ ) values was less than 0.05 and consequently the null hypotheses is rejected, and the attitudes were positive to some extent according to the plus ( $t$ ) value (6.063).

\section{Results of the second hypothesis}

The null of hypothesis is "There are no significance statistical differences at the significance level $(\alpha=0.05)$ 
Table 3. Means and percent means for the items.

\begin{tabular}{|c|c|c|c|c|c|}
\hline No. & & Item & Means * & $\begin{array}{l}\text { Percent } \\
\text { means }\end{array}$ & $\begin{array}{l}\text { Responses } \\
\text { degree }\end{array}$ \\
\hline $1-$ & 1 & $\begin{array}{l}\text { Religious awareness and the dangers of serials, movies and bad use of } \\
\text { social networking sites in homes, schools and mosques. }\end{array}$ & 3.46 & 86.5 & Very High \\
\hline $2-$ & 2 & Taking into account the appropriate age for both spouses. & 3.07 & 76.75 & High \\
\hline 3- & 3 & Each spouse should look for the right partner in terms of lineage. & 3.07 & 76.75 & High \\
\hline 4- & 4 & $\begin{array}{l}\text { Parents' understanding of the economic situation and reducing the costs } \\
\text { of marriage. }\end{array}$ & 3.3 & 82.5 & Very High \\
\hline $5-$ & 5 & $\begin{array}{l}\text { The disparity in the academic degrees between them should not be very } \\
\text { high. }\end{array}$ & 2.84 & 71 & High \\
\hline 6- & 6 & $\begin{array}{l}\text { Raising the awareness of those who marry on the importance of } \\
\text { marriage. }\end{array}$ & 3.3 & 82.5 & Very High \\
\hline 7- & 7 & $\begin{array}{l}\text { The selection of the other partner should be based on the appropriate } \\
\text { standards and criteria. }\end{array}$ & 3.61 & 90.25 & Very High \\
\hline 8- & 8 & The couple should share each other with grief and joy. & 3.38 & 84.5 & Very High \\
\hline 9- & 9 & $\begin{array}{l}\text { Young men and girls should be warned against the seriousness of pre- } \\
\text { marital relationships }\end{array}$ & 3.53 & 88.25 & Very High \\
\hline $10-$ & 10 & $\begin{array}{l}\text { Non-interference by the parents, but as it is most likely that for the } \\
\text { benefit of the couple. }\end{array}$ & 3.53 & 88.25 & Very High \\
\hline $11-$ & 11 & $\begin{array}{l}\text { It is very important for spouses to respect each other and not to try to } \\
\text { impose their control on each other. }\end{array}$ & 3.23 & 80.75 & Very High \\
\hline $12-$ & 12 & $\begin{array}{l}\text { The patience of both spouses and keep divorce to the last possible } \\
\text { decision. }\end{array}$ & 3.61 & 90.25 & Very High \\
\hline 13- & 13 & $\begin{array}{l}\text { Giving the suitors an enough period of time before the engagement to } \\
\text { think. }\end{array}$ & 3.38 & 84.45 & Very High \\
\hline $14-$ & 14 & $\begin{array}{l}\text { Providing job opportunities to help the husband in supporting family's } \\
\text { needs. }\end{array}$ & 3.23 & 80.75 & Very High \\
\hline $15-$ & 15 & $\begin{array}{l}\text { One pf the spouses' disliking something in the other, and tried to change } \\
\text { it gradually }\end{array}$ & 3.07 & 76.75 & High \\
\hline $16-$ & 16 & $\begin{array}{l}\text { Awareness of surroundings of the couple in how to deal with their } \\
\text { problems. }\end{array}$ & 3.15 & 78.75 & High \\
\hline $17-$ & 17 & Society awareness of the risks of divorce. & 3.61 & 90.25 & Very High \\
\hline $18-$ & 18 & Not to prolong the engagement period and not to shorten it. & 3.38 & 84.5 & Very High \\
\hline $19-$ & 19 & $\begin{array}{l}\text { If a woman is an employee, it is necessary to show their responsibility in } \\
\text { terms of material contribution to the family. }\end{array}$ & 3 & 75 & High \\
\hline $20-$ & 20 & $\begin{array}{l}\text { Provide the opportunity for the reform committees to carry out their } \\
\text { tasks at the time of the dispute. }\end{array}$ & 3.15 & 78.75 & High \\
\hline $21-$ & 21 & $\begin{array}{l}\text { Give ample opportunity for both spouses before the judge divides them. } \\
\text { Total }\end{array}$ & $\begin{array}{l}3.38 \\
3.14\end{array}$ & $\begin{array}{c}84.45 \\
78.5\end{array}$ & $\begin{array}{l}\text { Very High } \\
\text { High }\end{array}$ \\
\hline
\end{tabular}

*The highest degree to the item is (4) points.

in the views of Muftis at Dar Al-Ifta' Al-Falasteeniyya on the suggestions for divorce".

Table 5 shows that there are significance differences at the significance level $(\alpha=0.05)$ in "the views of Muftis at Dar Al-Ifta' Al-Falasteeniyya on the suggestions' for divorce" on total score and at all domains where the significance level for $(\mathrm{t})$ values was less than $(0.05)$ and consequently the null hypotheses is rejected, and the attitudes were positive to some extent according to the plus (t) value (19.020).

\section{CONCLUSION}

The study results indicate that the highest reasons for divorce from the perspective of the study participants were related to general weakness of society with the risks of divorce and its negative effects, technological development and the spread of social media such as Facebook and others. The lack of patience of both spouses and resort to divorce when any problems occur, age disparity between spouses, leads to weakness in understanding in their married life, the interference of parents with what happens negatively between spouses. 
Table 4. One-sample test.

\begin{tabular}{ccccccc}
\hline \multicolumn{6}{c}{ Test value $\mathbf{2 . 6}$} \\
\hline & $\mathbf{T}$ & df & Sig. (2-tailed) & Mean difference & \multicolumn{2}{c}{ 95\% confidence interval of the difference } \\
\cline { 3 - 6 } & & & & Lower & Upper \\
\hline Reasons of divorce & 6.063 & 12 & 0.000 & 0.43846 & 0.2809 & 0.5960 \\
\hline
\end{tabular}

Table 5. One-sample test.

\begin{tabular}{lcccccc}
\hline & \multicolumn{3}{c}{ Test value = 2.6 } & & & \\
\cline { 2 - 7 } & $\mathbf{t}$ & Df & Sig. (2-tailed) & Mean Difference & \multicolumn{2}{c}{ 95\% Confidence Interval of the Difference } \\
\cline { 3 - 7 } & & & & .600 & Lower & Upper \\
\hline Suggestions for divorce & 19.020 & 12 & .00670 & .6169 & .7765 \\
\hline
\end{tabular}

The study results indicate that the highest preferred solution to the issue of divorce from the perception of the study sample were related to young men and girls should be warned against the seriousness of pre-marital relationships; non-interference by the parents, but as it is most likely that for the benefit of the couple, the selection of the other partner should be based on the appropriate standards and criteria. The patience of both spouses and keep divorce to the last possible decision. Society awareness of the risks of divorce.

\section{Recommendations}

Based on the study results, the researcher recommends the following:

- Improve newly married couples of the negative impact of the interference of parents with what happens between spouses.

- Conduct workshops, conferences, on the issue of the risks of divorce and its negative effects.

- The suggestion for Dar Al-Ifta' Al-Falasteeniyya to refer married couples who wish to get a divorce to special training workshops, that teach them on the issue of patience of both spouses and resort to divorce when any problems occur, age disparity between spouses, leads to weakness in understanding in their married life; young men and girls should be warned against the seriousness of pre-marital relationships.

\section{REFERENCES}

Abuzant M (2016). Divorce: Reasons and Consequences from the Perspective of Divorced Women Afield -Based Study in the Area of Nablus City. https://hdl.handle.net/20.500.11888/8777.

Alan JH, Brian JW, William JD (2012). Reasons for Divorce and Openness to Marital Reconciliation, J. Divorce Remarriage 53(6):453-463. http://dx.doi.org/10.1080/10502556.2012.682898.

Al-Azozuni A (2016). The Marriage of the Immature. Early Execution. Jordan. Ar-Raya. 3(1):222-230.

Al-Khatib S (2009). Social changes and their impact on high divorce rates. Academic Essay. King Abd-Aziz University J. Facult. Arts. 17(1):159-166.

Al-Gharaibeh F, Bromfield N (2012). An analysis of divorce cases in the United Arab Emirates: A rising trend. J. Divorce Remarriage. 53(6):436-452. doi: 10.1080/10502556.2012.682896.

Al-Maliki A (2001). The phenomenon of Divorce in the United Arab Emirates and the Causes, Trends, Risks and Solution.

Allen ES, Atkins DC, Baucom DH, Snyder DK, Gordon KC, Glass SP (2005). Intrapersonal, interpersonal, and contextual factors in engaging in and responding to extramarital involvement. Clinical Psychology: Sci. Pract. 12(2):101-130.

As-Sartawi M (2012). Jurisprudence of Personal Status (1) Reprinted 9. Al-Quds Open University.

Bakalar N (2010). "Education, Faith, and a Likelihood to Wed." New York Times, March 22. Retrieved February 14, 2012 (http://www.nytimes.com/2010/03/23/health/23stat.html).

Employment and Social Development Canada. (2014a). "Indicators of Well-Being in Canada: Family Life - Divorce." Employment and Social Development Canada. Retrieved July 5, 2014, from http://www4.hrsdc.gc.ca/.3ndic.1t.4r@-eng.jsp?iid=76.

Heller V, Recoules M (2013). France. Changes in Divorce patterns: culture and the law.

Hawkins AJ, Willoughby BJ, Doherty WJ (2012). Reasons for divorce and openness to marital reconciliation. J. Divorce Remarriage. 53(6):453-463. doi: 10.1080/10502556.2012.682898.

Palestinian Central Bureau of Statistics. (2018). "Palestinian Central Bureau of Statistics P.O. Box 1647, Ramallah - Palestine Ramallah City, Ein Munjed Quarter, Tokyo St. opposite to UN premises and Ramallah Cultural Palace".

Scruton R (2012). 'Don't sacrifice marriage on equality's altar', The Times, 15 December.

Sinha M (2013). "Measuring violence against women: Statistical trends." Statistics Canada. Catalogue no. pp. 85-224-X. February 25. Retrieved July 5, 2014, from http://www.statcan.gc.ca/pub/85-002x/2013001/article/11766-eng.pdf.

Settersten RA Jr. (2015). Relationships in time and the life course: The significance of linked lives. Res. Hum. Dev. 12(3-4):217-223. doi:10.1080/15427609.2015.1071944.

Shalaby Y (1992). Divorce in Ramallah, it is social and statistical study.

Temke MW (2006). "The Effects of Divorce on Children." Durham: University of New Hampshire. Retrieved January 16, 2012.

Vitanen $T$ (2014). The Divorce Revolution and Generalized Trust: Evidence from the United States 1973-2010, IZA Discussion Papers, No. 7966, Institute for the Study of Labor (IZA), Bonn. 